\title{
Seasonal variation in supply and prices of strawberry in Minas Gerais' CEASA, BRAZIL
}

\author{
Wesley Augusto Florêncio Jordão ${ }^{1}$ (i) Luis Felipe Lima e Silva ${ }^{1^{*}}$ (1) \\ ${ }^{1}$ Departamento de Agronomia, Universidade José do Rosário Vellano (UNIFENAS), 37130-000, Alfenas, MG, Brasil. E-mail: luis.silva@unifenas.br. \\ "Corresponding author.
}

ABSTRACT: The research studied the seasonal variation in supply and prices of strawberry practiced in the state of Minas Gerais, represented by the units of the CEASAMINAS, as well as components of this supply for each major supply region in the state, in the period between 2016 and 2019. The CEASAMINAS unit (Greater Belo Horizonte) was responsible for $76 \%$ of the annual commercialization of strawberry in Minas Gerais, through the CEASAMINAS units, which fluctuated between 6038.4 and $7413.4 \mathrm{Mg}^{-1}$ yearly. In the periods of transition from winter to mid-season and summer, it is possible to observe striking variations in supply and prices of strawberry in market assessed, referring to the lowest productive averages and the highest average prices observed year to year. The seasonal variations in supply and prices of strawberry clearly reflected the need for new cultivars that can satisfactorily produce during the mid-season and high temperature months.

Key words: Fragaria x ananassa Duch. Ex Rozier, cultivation, productivities, seasonality, south of Minas Gerais.

Variação estacional da oferta e dos preços do morango na Ceasa de Minas Gerais

RESUMO: $O$ objetivo do trabalho foi estudar a variação estacional da oferta e dos preços do morango praticados no estado de Minas Gerais, representados pelas unidades da CEASAMINAS, bem como as componentes dessa oferta para cada principal região abastecedora do Estado, no periodo de 2016 a 2019. Os dados obtidos de oferta e de preços do morango praticados no estado de Minas Gerais foram processados utilizando-se metodologia da média geométrica móvel centralizada, para os cálculos dos índices de variação estacional. A unidade CEASAMINAS (Grande BH) foi responsável por 76\% da comercialização anual de morango em Minas Gerais por meio das unidades da CEASAMINAS, que oscilou entre e 6.038,4 e 7.413,4 toneladas anuais. As variações estacionais de oferta e de preços refletiram claramente a necessidade de novas cultivares que possam tolerar as grandes oscilações climáticas nos meses de meia estação e de verão. Também ficou evidente que, a despeito da deficiência da disponibilidade no mercado de cultivares mais adaptadas para a produção em clima tropical brasileiro, a produção de morango ainda é mais baixa em épocas mais quentes do ano, um reflexo provável das elevadas temperaturas, aliadas a elevados índices de precipitação e fotoperiodos mais longos, condições comuns nessas regiões nestes períodos e estações de transição e de verão, ocasionando assim as maiores perdas e baixos índices produtivos, bem como os maiores preços no mercado.

Palavras-chave: Fragaria x ananassa Duch. Ex Rozier, variação estacional, cultivo, oferta, preço.

\section{INTRODUCTION}

The strawberry is an accessory fruit much appreciated by the Brazilian population. It is a functional food since, besides its nutritional properties, it also possesses active substances that keep or improve the health of the human organism. In Brazil, the culture is scattered across regions of temperate and subtropical climate since they are the traditional producing regions of strawberry. The Fragaria is a species whose cultivated area has increased every year (SANTOS, 2003; IEA, 2007; VIEIRA, 2017). It stands out among the cultivated fruits due to its characteristics which attract the consumer market such as flavor, coloration, the smell and the nutritional value. It is a vegetable that presents, yet, versatility in consumption, being consumed both in natura and industrialized in the form of jelly, sweets or many other products that use it as base.

The Fragaria culture has been consolidating itself in the southern region of Minas Gerais, mostly in small properties, stimulated by the favorable climatic conditions, by the prime location in relation to the major consumption centers and by the strong profitability provided. In Brazil, the production contributes significantly to the generation of incomes 
and jobs and it is characterized as an activity with an intense use of workforce. Minas Gerais is the largest strawberry producer in Brazil, with emphasis on the south and southeast regions (VIEIRA et al., 2017).

The strawberry production is influenced by the interaction between temperature and photoperiod, with the short-day cultivars being the ones in which the flower induction happens ate the end of the summer or beginning of the autumn when the days are shorter $(<14$ hours) and the temperatures milder $\left(<16^{\circ} \mathrm{C}\right)$ (SANTOS, 2003). The short-day Fragaria cultivars mostly used in the southern region of Brazil are the 'Camarosa' and 'Camino Real' (OLIVEIRA \& SCIVITTARO, 2006) while, in the rest of the country, 'Oso Grande' is the one with the higher economic expression (ANTUNES \& REISSER JUNIOR, 2007).

Even in regions and times considered favorable, it is evident the existence of difficulties in the production of strawberries in Brazil. In general, in the productive regions of the country, the situation becomes more critical in the transition period between summer and autumn, in which the great oscillation between day and night temperatures, typical of the months of April and May, which can harm production, due to the formation of fruits of little commercial value, due to the thermal fluctuations (day/night) that occurred during the period, in addition to high temperature and photoperiod indexes (GALVÃO et al., 2014; VIEIRA et al., 2017). This fact reflects the common high prices observed at these times of the year in the wholesale and retail markets of Brazil (ANTUNES \& REISSER JUNIOR, 2019).

The low productivities reproductive in Brazil are mainly due to the use of cultivar badlyadapted to the edaphoclimatic conditions since Brazil has imported seedless from Argentinian and Chilean plant nurseries that multiply cultivars developed by programs of genetic enhancement of other countries, creating production costs and delays in planting, that can only begin at the end of April what is late for some regions that begin their cultivation in March such as São Paulo and Minas Gerais. In the absence of cultivars adapted to the national edaphoclimatic conditions, the producers have higher expenses since they also pay royalties indirectly (GALVÃO et al., 2014; VIEIRA et al., 2017).

Due to the existence of different producing regions, with different edaphoclimatic characteristics, under different technologies adopted and multiple cultivars available, the strawberry culture may show seasonal variation in the supply and prices practiced throughout the agricultural year.

Thus, the objective of this research was to analyze the seasonal variation in supply and prices of strawberry practiced in the state of Minas Gerais, represented by the Minas Gerais supply center (CEASAMINAS) units, in the period between 2016 and 2019. The jointly analysis of the data of production and supply of the culture can be used as basis for the planning of its production, as well as for the implantation of the culture in different regions with similar edaphoclimatic conditions that show potential for its production.

\section{MATERIALS AND METHODS}

The study was carried out with data made available by the Ceasa of Minas Gerais through the website www.ceasaminas.com.br. It was obtained data referring to the supply and prices of strawberry practiced in the state of Minas Gerais between the years of 2016 and 2019, monthly. The data were from the following CEASA MG units: Greater Belo Horizonte, Barbacena, Caratinga, Governador Valadares, Juiz de Fora and Uberlândia. In total, it was analyzed information from six units, with the data totaled and expressed in percentages.

The data were then processed by the software INDEVES (software for calculation of indexes of seasonal variation in prices, of the Department of Rual Economy and Sociology of the ESALQ USP, 1987). The software creates a numerical data file through the methodology known as centralized mobile geometric mean (SILVA et al, 2014). The result of the procedure is recorded in an output file from which it is obtained minimum, average and maximum indexes for the total supply of strawberry in the group of six CEASAMINAS units for the years between 2016 and 2019 as well as each of the individual producing regions.

The method of the centralized mobile geometric mean is indicated to calculate the seasonality of the production and prices in the form of annual or biennial data. This method is described by HOFFMANN (1991). The first step of the method consists in calculating centralized mobile geometric mean (MGM) for each month in the series of data from the period of months/years desired. Taking the month of January, 2016 as an example, and taking the Napierian logarithm of the production averages for the period, MGM is given by:

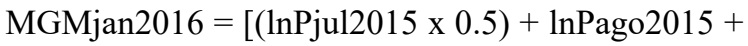
$\ldots+\ln$ Pjun $2016+(\ln P j u 12016 \times 0.5)] / 12$

With MGM being the mobile geometric mean and $\ln \mathrm{P}$ the Neperian logarithm of the production data relative to the month in question, for 
the calculation it is considered the production data of the month (January, for example) as well as the six previous months and the six following months, with the first and last month (July, 2013 July, 2014, in the example) being multiplied by 0.5 , in order to obtain the result relative to a 12 -month period. After the calculation of the mobile geometric means, the differences between the production data of each month and its mobile media are calculated. Also, the means of these differences are calculated for each month of the year, resulting in mean value from January to December, out of which the arithmetic means are computed.

The results of the calculations that do not equal to zero are corrected, taking, from each mean of the monthly difference, the respective arithmetic mean. For the calculation of the irregularity indexes (minimum and maximum indexes), first, the standard deviations are calculated for the results of the seasonal indexes of each month, then, the basis of the Neperian logarithm is elevated to each result. These numbers, when multiplied by the seasonal index obtained, resulted in the superior indexes, and, when divided, in the inferior indexes. Results were presented in figures.

Using the same methodology, it was obtained, also, minimum, average and maximum values for the variation in prices in the CEASAMINAS, during the same period, taking the Belo Horizonte region as representative for the state of Minas Gerais.

The results were clashed with the climatic data of each producing region in an attempt to explain the possible seasonal variations in supply and prices of strawberry in Minas Gerais in the period studied. The following climatic data were collected from the website of the National Institute of Meteorology (INMET-2020): precipitation, average maximum temperature, average minimum temperature and relative humidity, related to the weather stations of the major producing mesoregions. Data regarding the average altitude of the major producing regions were related to the ones obtained for their respective seasonal variations in supply.

\section{RESULTS AND DISCUSSION}

The commercialization of strawberry of CEASAMINAS' central supplies in Minas Gerais is consists of the regional units of Barbacena, Caratinga, Greater Belo Horizonte, Governador Valadares, Juiz de Fora and Uberlândia. The CEASAMINAS unit in Greater Belo Horizonte represented the largest supply of strawberry commercialization in the period between 2016 and 2019, around $76 \%$ of the strawberry, and; therefore, this unit was taken as representative of the supply and prices practiced in the period. The total supply of the commercialization of strawberry in the major CEASAMINAS units fluctuated between 6038.4 and $7413.4 \mathrm{Mg} \mathrm{ha}^{-1} /$ year, with an annual average of almost $6497.27 \mathrm{Mg} \mathrm{ha}^{-1}$.

In the period studied, it was commercialized, in the CEASAMINAS units in Minas Gerais, $31874.2 \mathrm{~kg}$ of strawberry, with the production centered in cities of the state. The regions responsible for most of the production of strawberry intended for CEASAMINAS were divided into 6 geographical mesoregions:

Triângulo Mineiro/Alto Parnaíba: consists of the following producing cities: Patos de Minas, Guimarania, Patrocínio, Serra de Salitre, Lagoa Formosa, Ibiá, Uberlândia, Santa Juliana, São Gotardo, Araguari, Monte Carmelo, Cruzeiro da Fortaleza.

Campo das Vertentes: consists of the following producing cities: Lagoa dourada, Barbacena, Tiradentes, Antônio Carlos, Ibertioga, Carandaí, Senhora dos Remédios, Alfredo Vasconcelos.

Northern Minas Gerais: consists of the following producing cities: Matias Cardoso, Varzelândia, Urucuia, Jaíba.

Zona da Mata: constitutes a mesoregion situated in the southeast portion of the state of Minas Gerais consists of seven major cities regarding the origin of the supply of strawberry in the Ceasa of Minas Gerais: Cataguases, Juiz de Fora, Manhuaçu, Muriaé, Ponte Nova, Ubá and Viçosa.

Belo Horizonte Metropolitan Area: origin of strawberry consists of: Belo Vale, Piedade dos Gerais and Contagem.

Southern and Southeastern Minas Gerais: origin of strawberry consists of the following major cities regarding the supply of strawberry in the Ceasa of Minas Gerais: Bom Repouso, Pouso Alegre, Cambuí, Estiva, Tuvolândia and Congonhal.

Out of the entire commercialized amount of strawberry in the CEASAMINAS, the Greater Belo Horizonte unit represented $76 \%$, followed by the Uberlândia (11\%), Juiz de Fora (10\%), Caratinga (1\%), Governador Valadares (1\%) and Barbacena (1\%). The strawberry market in Minas Gerais is marked by the high fluctuation of supply and prices throughout the year, and in some of the same periods year to year. Due to is high representability in the total of commercialized fruits in the state, the Belo Horizonte metropolitan area, the major representative of commercialized supply in the Greater Belo Horizonte Ceasa unit, was taken reference for the average of the prices and supplies practiced yearly in the state. 
The strawberry showcased significant seasonal variation in supply and prices practiced in the state during the period studied (Figure 1). In average, the supply is lower from January to April/ May, taking into consideration that April/May are usually the planting months of the culture specially in Southern Minas Gerais (FILGUEIRA, 2013). It is possible to see a significant seasonal variation in supply throughout the months, agricultural year to agricultural year (maximum and minimum indexes).

December was the year with the lowest average supply, and showed the highest variations

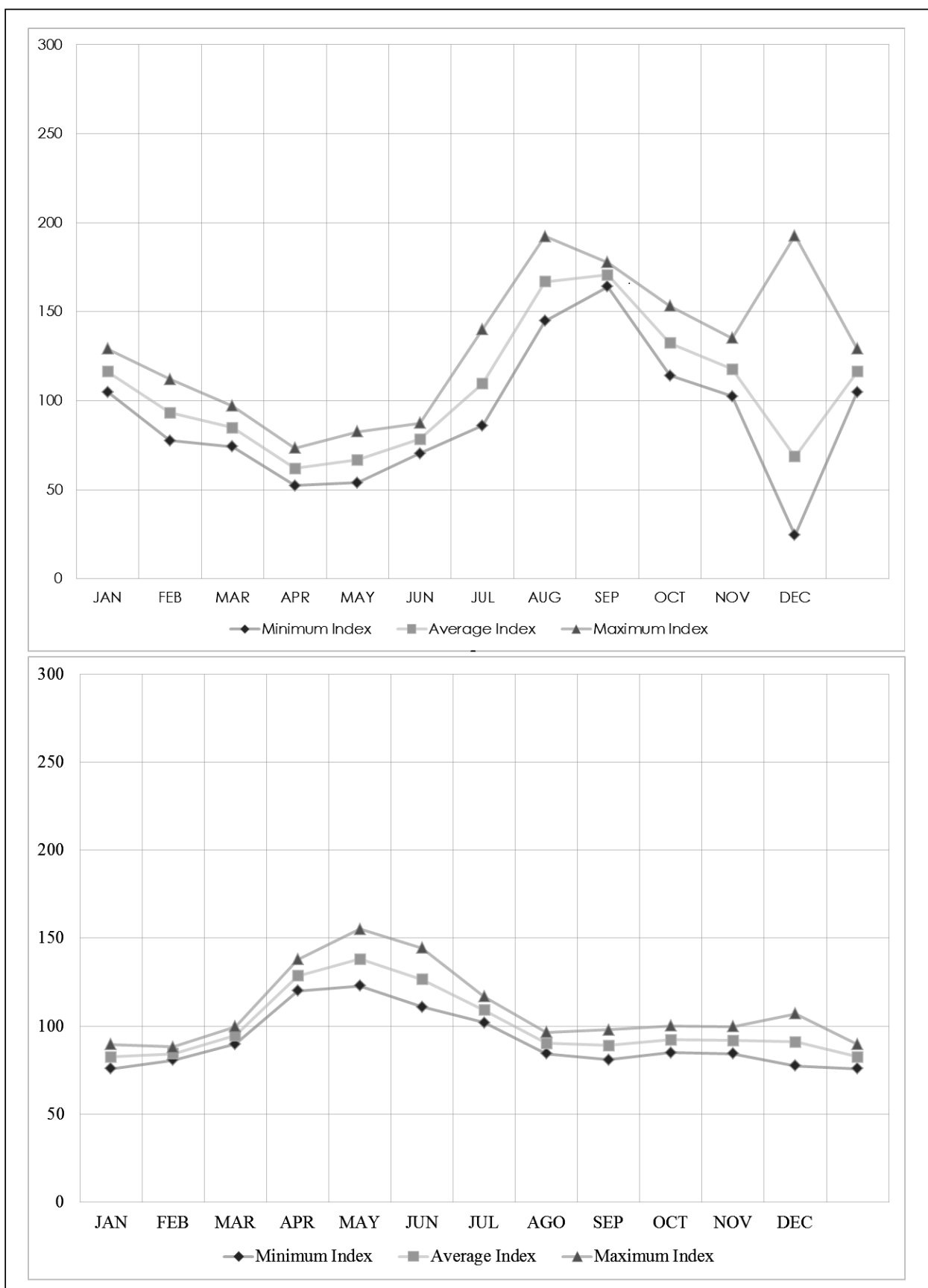

Figure 1 - Seasonal variation in the supply and prices of strawberry intended for CEASAMINAS - Greater Belo Horizonte between the years of 2016 and 2019. 
year to year with minimum index of 47.0 and maximum index of 137.39 , being the lowest and highest, respectively, of all the years analyzed. This period of lower supply corresponds to the transition from summer to autumn, with minimum typical temperature for this region of $14{ }^{\circ} \mathrm{C}$, average of 18 ${ }^{\circ} \mathrm{C}$ and maximum of $24^{\circ} \mathrm{C}$, and higher precipitation levels. The climatic conditions are unfavorable for the cultivation of strawberry in periods of higher temperatures, longer photoperiods and transition between climatic seasons (FILGUEIRA, 2013).

In the months of August and September, the highest average supplies occur, but with high variation year to year, especially in August when the amplitude between the minimum and maximum indexes was of 39 points. This period of higher supplies correspond to the beginning of the spring, with minimum typical temperature of $16.5{ }^{\circ} \mathrm{C}$, average of $20.5{ }^{\circ} \mathrm{C}$ and maximum of $28{ }^{\circ} \mathrm{C}$. Both the critical periods of the availability of strawberry in the market corresponded to mid-season periods (transition summer/autumn or winter/spring).

The average altitude of the producing cities in this mesoregion is 830 meters. High altitudes, hypothetically, favor the culture of strawberry. The study of adaptability and stability of genotypes is one of the most important factor for the development of new cultivars since the expression of the characters is conditioned to the genetic control of the organism, to the environment in which it is cultivated and to the interaction between these two factors (GALVÃO, 2014).

The Fragaria culture is, still, very influenced, specially, by the temperature, and, also, by the photoperiod. Even though there are cultivars of strawberry in the Brazilian market adapted to different photoperiods for the production of fruits (short and neutral photoperiods, specially), the temperature is still limiting for most of the cultivars currently available in Brazil (GALVÃO, 2014).

By analyzing the variations in price throughout the agricultural year, it is possible to observe that they have kept themselves relatively stable and under the average in the second semester of the year and at the start of the following year (August, September, October, November, December, January and February).

The lowest average price indexes were observed in the months of December and January, with 91.05 and 82.41, respectively. The highest average price indexes were observed in the months of April, May and June, with indexes of 128.65, 138.11 and 126.46 , respectively. There was a small variance in the average price indexes of around $10 \%$. As observed by Antunes \& Reisser Junior (2019), the months with highest supply of fruits are located between July and December, where the lowest prices occur. Meanwhile, the months between January and May present the lowest supplies and the highest prices.

The Fragaria production is influenced by the interaction between temperature and photoperiod in the entire state of Minas Gerais. The major cultivars available for production in Brazil are still imported, with the short-day cultivars as the ones in which the flower induction happens by the end of the summer or start of the autumn, when the days are shorter ( $<14$ hours) and the temperatures are milder $\left(<16^{\circ} \mathrm{C}\right)$ (GALVÃO, 2014; SANTOS, 2003).

According to Galvão (2014), the lack of programs of genetic enhancement in country is probably due to the complexity in the development of new cultivars, and, since the strawberry has an octaploid structure with high levels of heterozigosis, it is hard the separation of the phenotypic expressions resulting from the action of additive, dominant and epistatic components of the influence of the environment, making the enhancement harder.

It is important to highlight that one of the major bottlenecks of the commercialization of Fragaria fruits in Brazil today relates to the low postharvest durability. Thus the importance of selecting tougher genetic materials (DE SOUZA, 2017).

Even in the regions and periods considered favorable, it is evident the existence of bottlenecks in the strawberry production in the state of Minas Gerais. Usually, the production tends to be lower in the summer and mid-season months in which, even though there are cultivars adapted to the climate, the extreme temperature might lead to lower productions and, consequently, higher prices.

In all the producing regions in the state the situation becomes critic in the transition period between summer and autumn in which the high variation in day and night temperatures, typical for the months of April and May, can harm the production due to the formation of fruits of low commercial value because of thermal variations (day/night) that happen during the period besides high temperature and photoperiod indexes.

It is possible to observe high amplitude of variation in supply year to year in the month of May. In this month, there is the beginning of the off-season of strawberry in these regions, periods in which, usually, the implantation of the culture happens, especially in southern Minas Gerais. Mild winter temperatures associated to low precipitation make this season the most favorable to the implantation of the production. The highest supplies and lowest 
prices happen, specially, from July to September, a period that coincides with the post-harvest of the fruits in many producing regions.

In the metropolitan mesoregion of Greater Belo Horizonte, these high variations in supply and prices year to year happen, specially, in December. Due to the fact that these are periods with usually low average price, it is probable that the variations year to year might reflect, partially, the prices practiced in previous years during the same period, what may have influenced the decision of the producer regarding the total plantation area for the following year as well as the system to be used. However, oscillations in temperature between the day and night, usual during this transition between the end of the winter and the start of the spring, probably constitutes the reasons for this instability of supply. Short-day cultivars planted in this period may not present adequate behavior in years in which the temperatures are higher or lower than the ones usually expected.

The regions of high altitude are, usually, considered favorable for the cultivation of strawberry throughout the year if the cultivars are planted accordingly to each season of the year. In the summer, usually, there a predominance of plantations in March/April and short-day cultivars for harvest between August and October. In the winter, there is a predominance of plantation after July and up to September, for harvests, usually, in the off season between November and March, choosing the use of long-day and neutral cultivars. The varieties of neutral photoperiod are not influenced by the duration of day (photoperiod) even though they are strongly influenced by the temperature. The choice of the cultivar is essential for the results since a big part of the strawberry cultivars is sensible to the photoperiod, that being, the amount of hours of light in one day. According to what was observed by Roque (1998), the photoperiod conditions the physiology of the strawberry in the flower induction, and the temperature in vegetative growth for the reproduction of seedling, and the amount of cold hours in the quality of the seedling in function of the accumulation of reserve substances during its formation.

The strawberry culture showed seasonal variation in supply and prices practiced in the Minas Gerais Ceasa units during the period studied. Results clearly show that, usually, periods with higher temperatures and longer photoperiods, such as periods of climatic transition between seasons, are still bottlenecks for the supply of strawberry in the market. Consequently, these periods showed the highest prices for the product in the market. The results clearly indicated that there is, still, a big demand that new strawberry cultivars, adapted for the production in these climatic conditions, are developed.

\section{CONCLUSION}

The strawberry showed significant seasonal variation in supply and prices practiced in the state, represented by the CEASAMINAS units. In every producing region in the state, the highest variations were seen in the transition periods between summer and autumn. These results indicated that there is a big demand for the development of new strawberry cultivars adapted to the production in national climates, specially, in these periods of weather transitions.

\section{ACKNOWLEDGEMENTS}

The authors are grateful to the Coordenação de Aperfeiçoamento de Pessoal de Nível Superior - Brazil (CAPES) - Financing Code 001.

The José do Rosário Vellano University, Alfenas, Brazil, by infrastructure.

\section{DECLARATION OF CONFLICT OF INTEREST}

The authors declare no conflict of interest. The founding sponsors had no role in the design of the study; in the collection, analyses, or interpretation of data; in the writing of the manuscript, and in the decision to publish the results.

\section{AUTHORS' CONTRIBUTIONS}

Conceptualization, data acquisition, design of methodology and data analysis, prepared the draft of the manuscript: LFLS and WG. All authors critically revised the manuscript and approved of the final version.

\section{REFERENCES}

ANTUNES, L. E. C.; REISSER JÚNIOR, C. Fragole, i produttori brasiliani mirano all' esportazione in Europa. Rivista di Frutticoltura e di Hortofloricoltura, v.69, n.5, p.6064, 2007. Available from: <https://dialnet.unirioja.es/servlet/ articulo? codigo $=2310606>$. Accessed: Feb. 18, 2020.

ANTUNES, L.E.C.; REISSER JUNIOR, C. Morango: qualidade dita o preço. Anuário HF-2019. Uberlândia-MG, n.7, janeiro, p.93-98, 2019. Available from: <https://www.alice.cnptia.embrapa.br/bitstream/ doc/1120835/1/LuisEduardoArtigoMorangoAnuarioHF2019.pdf>. Acessed: Apr. 22, 2021.

CEASAMINAS - Centrais de Abastecimento de Minas Gerais S.A. Dados de Mercado. Available from: <http://www.ceasaminas. com.br/informacoesmercadogeral.asp >. Accessed: Nov. 22, 2020.

DE SOUZA, D. C.; et al.,. Propriedades físico-químicas em frutos de híbridos experimentais de morangueiro. Agrotrópica, 
v.29, n.1, p.85-96, 2017. Available from: <https://www.gov.br/ agricultura/pt-br/assuntos/ceplac/publicacoes/revista-agrotropica/ artigos/2017-DOI-10.21757/0103-3816-2017v29n1p85-96.pdf> doi: $10.21757 / 0103-3816.2017 \mathrm{v} 29 \mathrm{n} 1 \mathrm{p} 85-96$.

DE SOUZA, D. C.; et al. Variabilidade genética entre cultivares comerciais e híbridos experimentais de morangueiro com ênfase em análise de múltiplos fatores. MAGISTRA, v.30, p.48-59, 2019. Available from: <http://magistraonline.ufrb.edu.br/index. php/magistra/article/view/725>. Accessed: Nov. 22, 2020. ISSN $2236-4420$

ESCOLA SUPERIOR DE AGRICULTURA "LUIZ DE QUEIROZ"( ESALQ/ USP). INDEVES: Programa para cálculo de índices de variação estacional de preços. Departamento de Economia e Sociologia Rural da ESALQ/ USP. CD-ROM. 1987.

FILGUEIRA, F. A. R. Novo manual de olericultura: agrotecnologia moderna na produção e comercialização de hortaliças. 3rd edn. UFV, Viçosa, 2013.

GALVÃO, A. G.; et al. Over coming strawberry achene dormancy for improved seedling production in breeding programs. Idesia, Chile, v.32, n.4. 57-62p. 2014. Available from: <https://dialnet. unirioja.es $/$ servlet $/$ articulo? codigo $=5487347>$. Accessed: Jun. 22 , 2020. doi: 10.4025 .

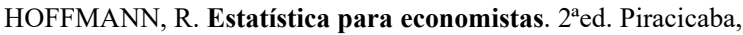
Biblioteca Pioneira de Ciências Sociais. 426p. 1991.
IEA - Instituto de Economia Agrícola. Pólos de produção do morango, 2007. Available from: <http://www.iea.sp.gov.br/out/ vertexto.php?codtexto=11/>. Accessed: Nov. 22, 2020.

INMET - Instituto Nacional de Meteorologia. 2020. Dados climáticos dos municípios de Minas Gerais em 2020. Available from: <http://portal.inmet.gov.br/>. Accessed: Oct. 22, 2020.

OLIVEIRA, R. P.; SCIVITTARO, W. B. Desempenho produtivo de mudas nacionais e importadas de morangueiro. Rev. Bras. Frutic., Jaboticabal, v.28, n.3, p.520-522, Dec. 2006. Available from: $\quad<$ https://www.scielo.br/scielo.php?script=sci_arttext\&pid $=$ S0100-29452006000300040>. Accessed: Apr. 23, 2021. doi: 10.1590/S0100-29452006000300040.

SANTOS, A. M. Cultivares. In: Santos, A. M.; Medeiros, A. R. M. (Eds.) Morango: produção. Brasília, Embrapa Informação Tecnológica. p.24-30. Frutas do Brasil, 40p. 2003.

SILVA, L. F. L.; et al. Variação estacional da oferta e preços de couveflor em Minas Gerais. Revista Ceres, v.61, n.3, p.323-331, 2014. Available from: <https://www.scielo.br/scielo.php?pid=S0034737X2014000300004\&script $=$ sci_arttext $>$. Acessed: Nov. 22, 2020. doi: 10.1590/S0034-737X2014000300004.

VIEIRA, S. D.; et al., Selection of experimental strawberry (Fragaria x ananassa) hybrids based on selection indices. Genetics and Molecular Research, v.16, n.1. 2017. Available from: <http://www.funpecrp. com.br/gmr/year2017/vol16-1/pdf/gmr-16-01-gmr.16019052.pdf>. Accessed: Dec. 20, 2020. doi: 10.4238/gmr16019052. 